\title{
PERBAIKAN DESAIN KEMASAN STIK ALE-ALE DAN STIK KANGKUNG PRODUKSI KUB WIDA MANTOLO DI KECAMATAN BENUA KAYONG KABUPATEN KETAPANG
}

\author{
Adha Panca Wardanu' ${ }^{1)}$, Martanto ${ }^{2)}$, Uliyanti ${ }^{3)}$ \\ ${ }^{1)}$ Progam Studi Agroindustri, Jurusan Pengelolaan Hasil Perkebunan \\ Politeknik Negeri Ketapang \\ ${ }^{2,3}$ Program Studi Teknologi Pangan, Jurusan Teknologi Pangan \\ ${ }^{3}$ Politeknik Tonggak Equator \\ e-mail: ${ }^{1)}$ ap_wardhanu@yahoo.co.id ${ }^{2)}$ martanto2000@yahoo.com \\ 3) iynt_lia@yahoo.com
}

\begin{abstract}
Abstrak
Tujuan dari kegiatan pengabdian kepada masyarakat (PKM) ini adalah membantu memperbaiki desain kemasan mitra agar menarik dan marketable dengan harapan mitra dapat berkembang dan bersaing di pasar yang kompetitif. UKM mitra dalam kegiatan PKM adalah KUB Wida Mantolo dan UKM Karya Mandiri bergerak di bidang pengolahan makanan terutama pengolahan produk olahan perikanan. Kedua UKM mitra memiliki permasalahan yang sama tentang kemasan yang digunakan, yaitu kemasan primer yang masih kurang menarik. Hasil kegiatan menunjukkan bahwa introduksi kemasan yang marketable dapat memberikan dampak positif bagi kedua UKM, yaitu penggunaan kemasan primer yang dikombinasi dengan Kemasan sekunder yang terbuat dari kemasan dus. Kemasan tersebut memiliki tampilan yang lebih baik dan informasi yang lengkap sehingga menjadikan image produk lebih meningkat.
\end{abstract}

Kata Kunci: Kemasan, Pemasaran, UKM, Ketapang

\section{PENDAHULUAN}

Kendala yang sering muncul dalam upaya pengembangan UMKM adalah Modal, Sumber daya manusia (SDM), hukum, akuntabilitas, Iklim usaha, infrasturktur dan akses (LPPI, 2015). Pernyataan tersebut juga di perkuat Sudaryanto, Ragimun dan Wijayanti. R.R, (2014), yang menyatakan bahwa UMKM di negara-negara Asean pada umumnya juga mempunyai permasalahan yang sama dalam pengembangan bisnisnya antara lain kendala hukum dan regulasi pemerintah, kualitas produk dan daya saing, perpajakan, informasi pasar, kualitas SDM, dan keahlian dalam pemasaran. Di samping itu kendala yang paling sulit adalah akses pinjaman atau kredit.

Kendala-kendala tersebut juga dirasakan oleh Kelompok Usaha Bersama (KUB) Wida Mantolo dan Usaha Kecil Menengah (UKM) Karya Mandiri yang ada di Kecamatan Benua Kayong Kabupaten Ketapang. KUB Wida Mantolo dan UKM Karya Mandiri bergerak di bidang pengolahan makanan terutama pengolahan 
produk olahan perikanan. Adapun produk yang dihasilkan kedua UKM tersebut termasuk stik dan rempeyek ale-ale, kerupuk tulang ikan dan amplang, serta kerupuk dan ikan. Berdasarkan survei dan diskusi langsung antara tim PKM dan Mitra, diketahui bahwa proses pengolahan yang dilakukan oleh KUB Wida Mantolo cukup sederhana. Teknologi yang digunakan maupun kapasitas olah yang dimiliki masih bervariasi tergantung jumlah pesanan, namun umumnya KUB Wida Mantolo hanya mampu memproduksi 7-15 kg per hari. Selain itu, kualitas kemasannya masih rendah dan kurang menarik.

KUB Wida Mantolo masih menggunakan kemasan yang sederhana dan terlihat tidak menarik sehingga tidak marketable. Kemasan primer yang digunakan KUB Wida Mantolo adalah kemasan plastik yang disablon. Bagi KUB Wida Mantolo kemasan hanya dipandang sebagai pembungkus semata bukan sebagai media pemikat konsumen dan kemasan juga dianggap penyebab ongkos produksi yang tinggi. Kondisi ini menjadi kendala bagi KUB Wida Mantolo untuk berkembang dan memasuki pasar yang kompetitif. Agar mampu bersaing dengan produk-produk lain yang sudah ada di pasaran, mau tidak mau KUB Wida Mantolo harus merubah tampilan produk agar tampak lebih menarik untuk meningkatkan personal branding produknya.
Menurut Siregar, R.A.D, (2017), salah satu cara yang dapat dilakukan UMKM dalam meningkatkan kualitas produknya yaitu dengan memaksimalkan fungsi kemasan. Hal tersebut sesuai dengan pendapat Cenadi (2000) yang

menyatakan bahwa kemasan bukan lagi sebagai pelindung ataumenjual produk yang dikemasnya dan berfungsi sebagai media komunikasi.

Berdasarkan analisis situasi tersebut maka perlu ada suatu upaya untuk memberikan solusi alternatif yang mampu meningkatkan daya saing produk-produk KUB Wida Mantolo melalui re-desain kemasan. Berdasarkan latar belakang tersebut tujuan dari kegiatan pengabdian kepada masyarakat ini adalah membantu memperbaiki desain kemasan mitra agar menarik dan marketable dengan harapan kinerja mitra dapat berkembang dan bersaing di pasar yang kompetitif.

\section{METODE}

Metode pelaksanaan kegiatan Pengabdian Kepada Masyarakat (PKM) yang dilakukan pada Mitra KUB Wida Mantolo berdasarkan dari hasil analisis situasi yang telah dilakukan dan disepakati oleh mitra sebagai bentuk solusi yang ditawarkan terdiri dari dua kegiatan.

\section{Rancangan Kegiatan}

Kegiatan ini dilaksanakan di unit produksi KUB Wida Mantolo yang terletak di Desa Baru, 
kecamatan Benua Kayong menjadi tiga tahap yaitu persiapan, Kabupaten Ketapang pada bulan pelaksanaan, dan tahap finalisasi. Februari sampai dengan Desember 2018. Pelaksanaan kegiatan terbagi

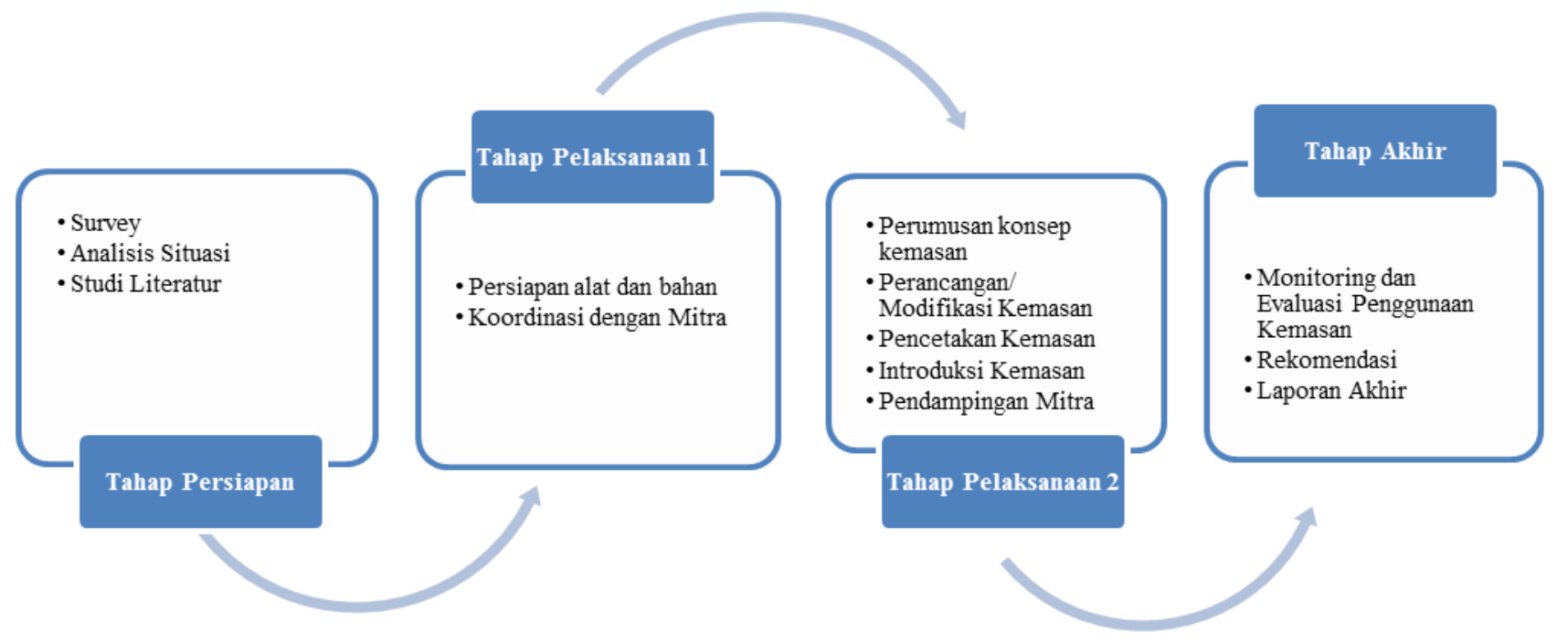

Gambar 1. Tahap Pelaksanaa Kegiatan PKM

\section{Prosedur Pelaksanaan}

Pelaksanaan kegiatan terdiri dari :

Tahap Persiapan

Kegiatan Survey bertujuan untuk mengetahui keadaan atau lokasi unit produksi mitra kerja dan objek-objek yang akan dikaji. Pada tahap ini tim pelaksana melakukan visitasi lapangan ke tempat mitra yaitu di Jalan Pangeran Hidayat II Desa Baru, Kecamatan Benua kayong. Pada kegiatan ini juga Tim pelaksana melakukan analisis situasi untuk mendapatkan gambaran mengenai masalah yang dihadapi Mitra. Untuk mendapatkan gambaran masalah mitra, tim pelaksana melakukan wawancara dan pengambilan dokumentasi di lokasi terutama mengenai karakteristik produk yang akan dikemas dan kelemahan atau kekurangan kemasan yang saat ini digunakan serta konsep kemasan yang akan diterapkan. Dari hasil analisis situasi yang diperoleh, maka dirumuskan dan dipilih masalah yang dijustifikasi oleh mitra. Permasalahn yang telah dijustifikasi oleh mitra kemudian dijadikan dasar oleh tim pelaksana untuk menentukan solusi yang ditawarkan melalui kajian atau studi literatur yang terkait atau relevan dengan masalah yang dihadapi mitra. Dari hasil tersebut muncul bentuk-bentuk solusi yang ditawarkan oleh tim pelaksana yaitu sosialisasi, penerapan teknologi kemasan, monitoring dan evaluasi serta pendampingan.

Tahap Pelaksanaan 
Dalam hal ini tim pelaksana dan mitra saling berkoordinasi mengenai persiapan pelaksanaan kegiatan pengabdian pada masyarakat yang terkait dengan sarana dan prasarana, serta peralatan yang dibutuhkan selama kegiatan PKM. Koordinasi yang dilakukan juga terkait dengan waktu dan tempat pelaksanaan kegiatan PKM. Pada tahap ini juga tim pelaksana dan mitra berdiskusi untuk mencari informasi mengenai aspek-aspek kemasan yang akan diperbaiki. Informasi yang diperlukan pada tahap ini meliputi unsur grafis yaitu warna, bentuk, logo dan merek, ilustrasi, huruf, dan tata letak. Sedangkan daya tarik praktis atau fungsional termasuk dapat melindungi produk, mudah dibuka atau ditutup kembali untuk disimpan, porsi yang sesuai untuk produk makanan/minuman, dapat digunakan kembali (reusable), mudah dibawa, dijinjing atau dipegang; dan memudahkan pemakai untuk menghabiskan isi kemasan dan mengisi kembali dengan jenis produk yang dapat diisi ulang. Kegiatan perbaikan kemasan dilakukan untuk memperbaiki kemasan produk agar lebih menarik atau marketable, yaitu :

1. Tim pelaksana mengidentifikasi kemasan yang selama ini digunakan oleh mitra dengan cara berdiskusi dan wawancara untuk mendapatkan konsep desain kemasan, baik dari segi material yang digunakan maupun ukuran.

2. Tim pelaksana memodifikasi penggunaan kemasan dus sebagai kemasan sekunder dengan kemasan primer yang sudah digunakan.

3. Tim pelaksana mendesain kemasan sekunder berbentuk dus yang terbuat dari kertas doove dengan dimensi ukuran tinggi 18 $\mathrm{cm}$, lebar $12 \mathrm{~cm}$, tebal $10 \mathrm{~cm}$ yang di dalamnya dapat memuat 80-250 gram stik ale-ale dan stik kangkung.

4. Hasil rancangan Tim pelaksana didiskusikan dengan mitra, untuk menyelaraskan dengan ide dan keinginan mitra.

5. Tim pelaksana memesan kemasan pada percetakan.

6. Setelah cetakan selesai dibuat maka tim pelaksana mengintroduksikan kepada Mitra.

7. Tim melakukan pendampingan penggunaan kemasan tersebut

\section{Tahap Finalisasi}

Kegiatan evaluasi dan monitoring dilakukan untuk mengetahui sejauh mana manfaat perbaikan kemasan yang dilakukan terhadap produk dan peningkatan penjualan setelah menggunakan kemasan yang telah diperbaiki. Pada tahap ini juga tim pelaksana memberikan rekomendasi kepada mitra terkait cara penggunaan dan penyimpanan kemasan. Pada tahap akhir kegiatan ini tim pelaksana menyusun laporan hasil kegiatan bersama mitra.

\section{HASIL DAN PEMBAHASAN}

\section{A. Hasil Perbaikan Kemasan}

Daya tarik visual

Hasil diskusi antara mitra dan tim 
pelaksana kemudian dijadikan sebagai dasar untuk merancang konsep kemasan yang akan dimodifikasi. Berdasarkan hasil identifikasi dan penilaian terhadap kemasan mitra ada beberapa hal yang perlu diperbaiki agar kemasan

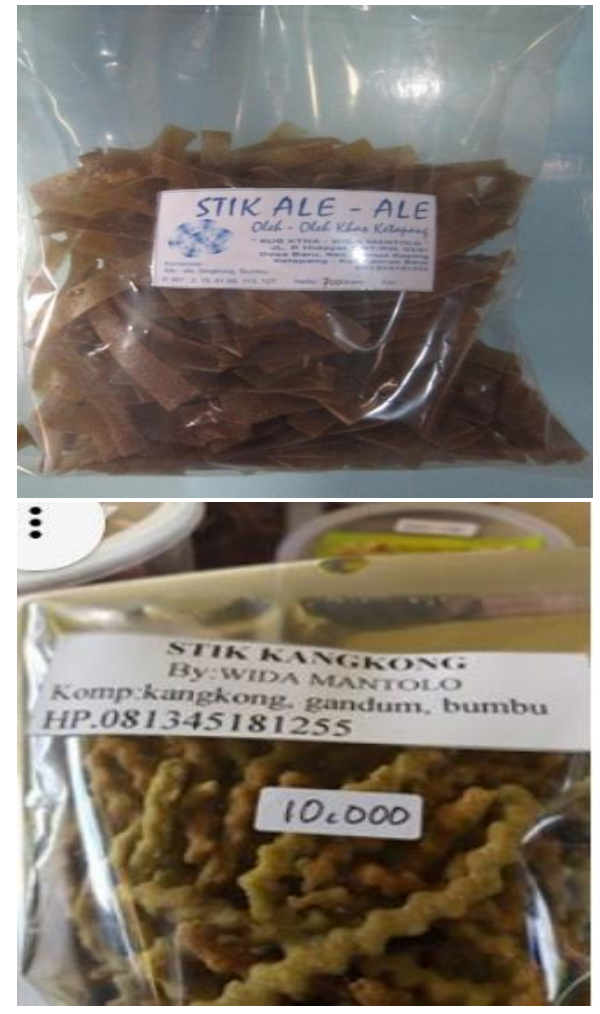

\section{Gambar 2. Kemasan Stik Ale-ale Sebelum dan Sesudah Dimodifikasi}

Kemasan produk mitra sebelum dimodifikasi terbuat dari jenis plastik transparan yang di sablon dan diberi informasi terkait nama produk, logo, nomor PIRT, komposisi, alamat produksi, namun belum mencantumkan berat bersih produk dan tanggal kedaluwarsa.

Selain itu, warna putih pada kemasan juga dinilai kurang menarik dan warna tulisan berwarna merah pada transparan tidak terbaca jelas.

produk menarik yaitu jenis kemasan, warna, bentuk, tata letak dan ilustrasi pada kemasan serta logo. Tampilan kemasan yang belum dimodifikasi dan sesudah dimodifikasi dapat dilihat pada Gambar 2.
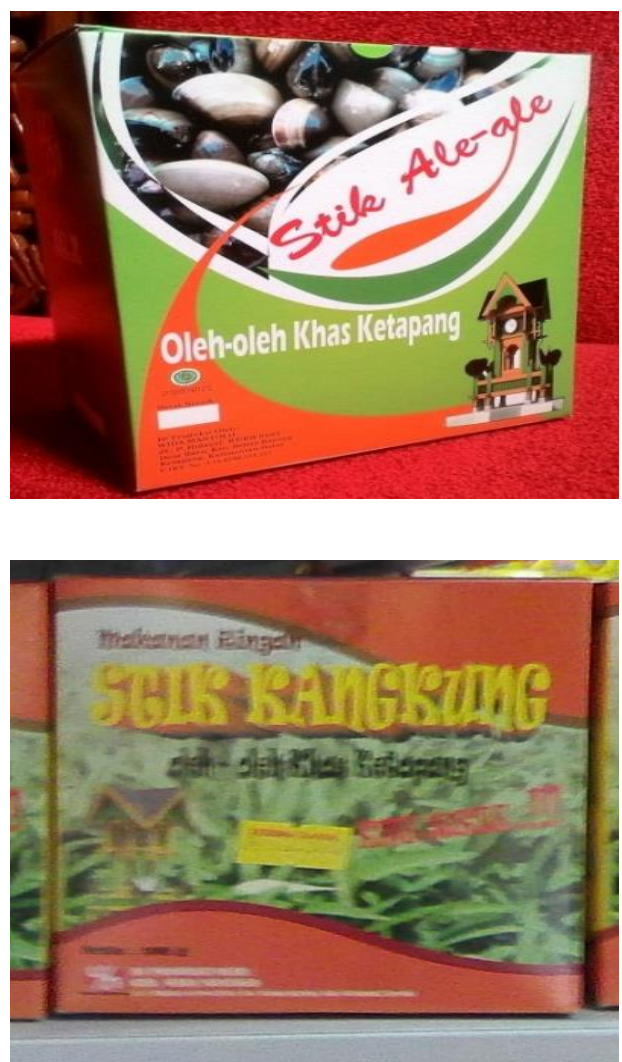
Kekurangan lainnya adalah tulisan pada kemasan yang di sablon luntur apabila terkena minyak dari produk, sehingga menyebabkan tulisan tidak terbaca dengan baik. Untuk itu diperlukan perbaikan pada kemasan tersebut agar dapat menarik minat konsumen.

Perbaikan kemasan sangat diperlukan oleh mitra karena kemasan merupakan hal yang 
penting dalam suatu usaha makanan. Menurut Klimchuck dan Krasovec (2006) desain kemasan adalah alat komunikasi yang mengkaitkan bentuk, struktur, metarial, warna, citra, tipografi, dan elemen-elemen, desain dengan informasi produk agar produk dapat dipasarkan. Desain kemasan berlaku untuk mem bungkus, melindungi, mengirim, mengeluarkan, menyimpan, meng identifikasi, dan membedakan sebuah produk di pasar. Selain itu Cenadi, C.S, (2000), juga berpendapat bahwa, agar suatu produk berhasil, maka penampilan sebuah kemasan harus mempunyai daya tarik.

Daya tarik visual mengacu pada penampilan kemasan yang mencakup unsur-unsur grafis yaitu

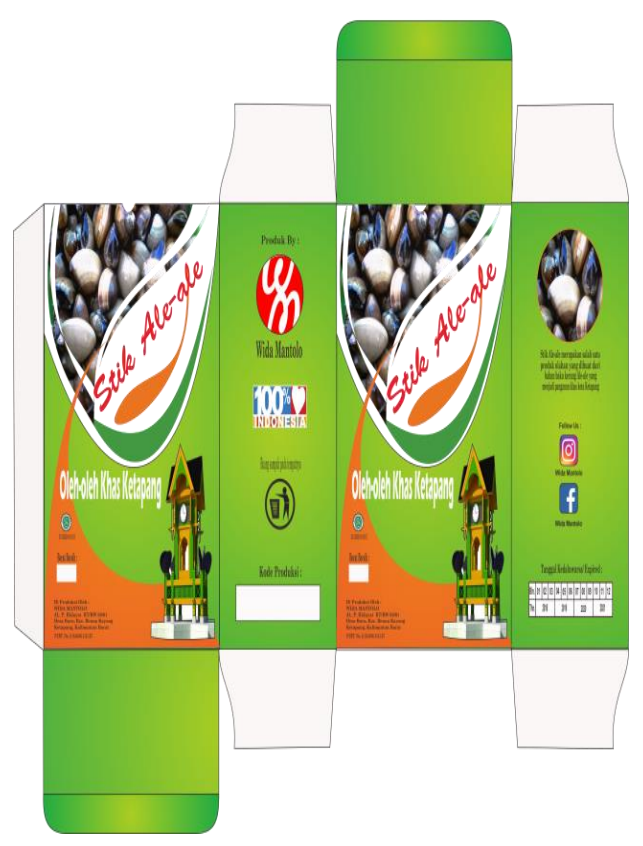

warna,bentuk, logo dan merek, ilustrasi, huruf, dan tata letak.

Dari hasil pertimbangan tersebut maka dilakukan modifikasi terkait jenis kemasan, tata letak, bentuk, warna, ilustrasi dan informasi lainnya yang kurang atau tidak terdapat pada kemasan sebelumnya. Untuk itu, Tim pelaksana mengintroduksikan memodifikasi penggunaan kemasan dus berukuran $16 \mathrm{~cm} \times 12 \mathrm{~cm}$ dan $10 \mathrm{~cm}$ sebagai kemasan sekunder dan kemasan plastik polos sebagai kemasan primer. Hal tersebut dimaksudkan agar kemasan lebih menarik, mudah di distribusikan, dan tidak luntur tulisannya. Kemasan hasil modifikasi dapat dilihat pada Gambar 3.

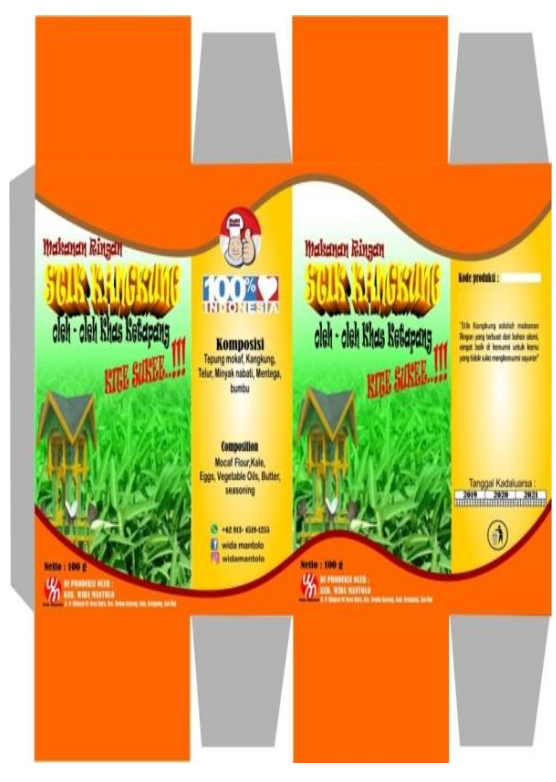

Gambar 3.

Kemasan Stik Ale-ale dan Stik Kangkung sesudah Dimodifikasi 
Warna kemasan hasil modifikasi dipilih warna hijau dengan kombinasi orange. Pemilihan warna tersebut merupakan hasil diskusi bersama mitra. Dasar pemilihan warna tersebut untuk meningkatkan daya tarik konsumen. Menurut Siregar, R.A.D (2017), Warna merupakan salah satu aspek yang paling berpengaruh dari desain kemasan. Konsumen lebih mengidentifikasi warna kemasan atau produk sebelum fitur visual lainnya. Warna membedakan kepribadian, menarik perhatian terhadap atribut-atribut lainnya, dan memungkinkan untuk membuat perbedaan dari kompetitor dalam lingkungan ritel.

Pencantuman logo juga dibubuhkan pada kemasan yang dimodifikasi, karena sebelum dimodifikasi logo tidak dibubuhkan dalam kemasan. Logo merupakan identitas produk yang sesuai dengan produk, khas, berbeda dengan logo lainnya, dan mudah diingat oleh pembeli. Logo yang ditampilkan merupakan logo dari KUB Wida Mantolo yang merupakan simbol dari akronim Wida Mantolo yaitu WM yang ditulis serangkai dengan latar belakang merah dan berbentuk bulat. Hal ini sesuai dengan pendapat Natadjaj, dkk. (2009) bahwa membuat logo hendaknya yang simple yang menggambarkan ciri khas, mudah dijelaskan, menggugah, mengandung keaslian dan tidak mirip dengan logologo produk lain.
Selain warna dan logo yang tak kalah penting unsur gambar/ ilustrasi pada kemasan. Suatu kemasan dipandang akan lebih berdaya tarik bila dibubuhi ilustrasi. Pada kemasan sebelumnya, tidak terdapat ilustrasi atau gambar pada kemasan sehingga tidak menarik minat konsumen. Pada kemasan yang dimodifikasi ilustrasi atau gambar yang dibubuhkan adalah gambar khas yang menggambarkan bahan baku dari produk yaitu kerang ale-ale untuk kemasan stik ale-ale dan kangkung untuk kemasan stik kangkung. Kemudian juga ditambahkan gambar tugu ale-ale yang merupakan ciri khas dari Kota Ketapang untuk memberi kesan produk asli kota Ketapang. Klimchuk dan Krasovec (2006) berpendapat bahwa foto yang cantik atau ilustrasi makanan yang lezat secara efektif membuat produk tampak menonjol dibandingkan dengan produk lainnya.

\section{Daya tarik Fungsional Kemasan}

Daya tarik praktis atau fungsional meliputi: dapat melindungi produk, mudah dibuka atau ditutup kembali untuk disimpan, porsi yang sesuai untuk produk makanan/minuman, dapat digunakan kembali (reusable), mudah dibawa, dijinjing atau dipegang dan memudahkan pemakai untuk menghabiskan isinya dan mengisi kembali dengan jenis produk yang dapat diisi ulang (Siregar, R.A.D, 2017). 
Kemasan yang telah didesain dan dicetak kemudian diintroduksikan ke Mitra.

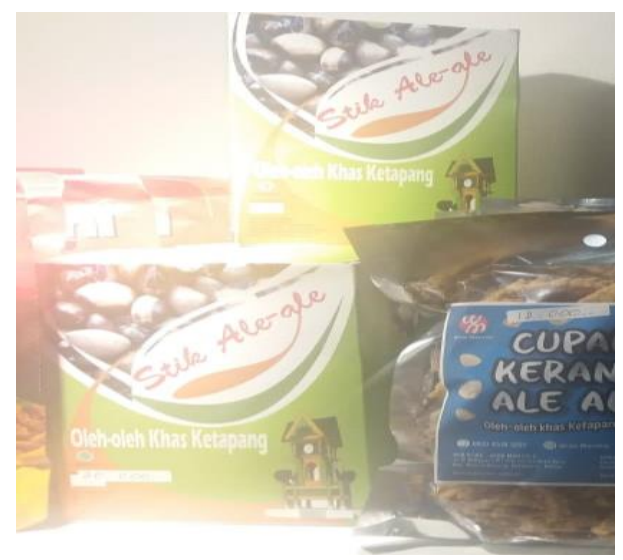

Hasil penerapan yang telah dilakukan mitra dapat dilihat pada Gambar 4.

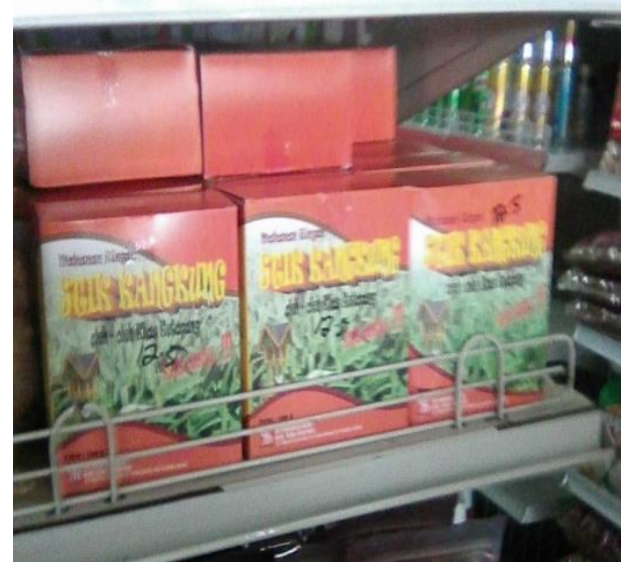

Gambar 4.

Kemasan Hasil Modifikasi

Bentuk kemasan kotak Selain itu, penggunaan kemasan kotak memudahkan saat pendistribusian kardus sebagai kemasan sekunder produk dan pada saat penyimpanan di juga dapat menjadi pelindung produk rak pemajangan produk di toko sehingga lebih aman. Kemasan dapat sehingga dapat disusun rapi. Hal dengan mudah untuk dibuka maupun tersebut merupakan kelebihan ditutup. Bahan kardus/ kertas yang kemasan yang didesain dengan kotak digunakan kemasan ini dinilai oleh dibandingkan dengan kemasan sebagian responden dapat digunakan sebelumnya.

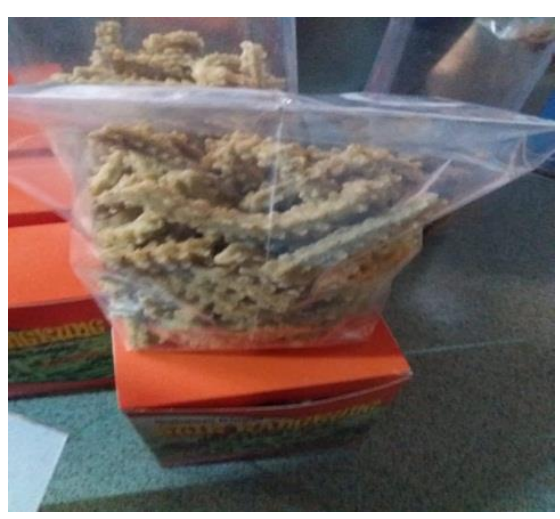

Gambar 5.

Kemasan Primer dan sekunder Stik Kangkung berulang kali. Hal tersebut juga didukung oleh sifat kardus/kertas yang memiliki daya tahan lama untuk digunakan sebagai kemasan (Siregar, R.A. D., 2017)

\section{C.B. Respon Konsumen Terhadap Kemasan}

Tanggapan atau respon konsumen terhadap kemasan hasil modifikasi menunjukkan hasil yang positif. Artinya konsumen memberikan tanggapan yang baik terhadap kemasan baru. Tanggapan konsumen terhadap kemasan baru stik 
ale-ale dan stik kangkung dapat dilihat pada Gambar 6.

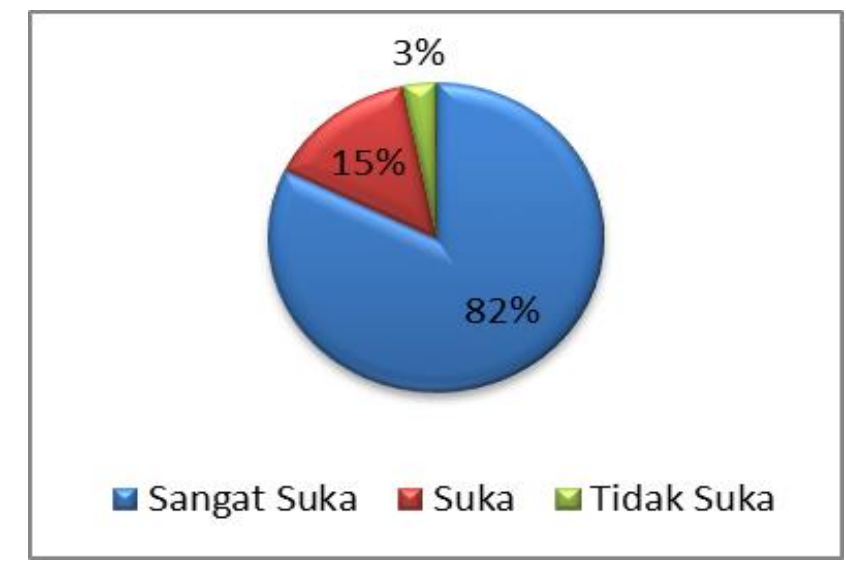

Gambar 6.

Tanggapan Konsumen terhadap Kemasan Stik Ale-ale Sesudah dimodifikasi

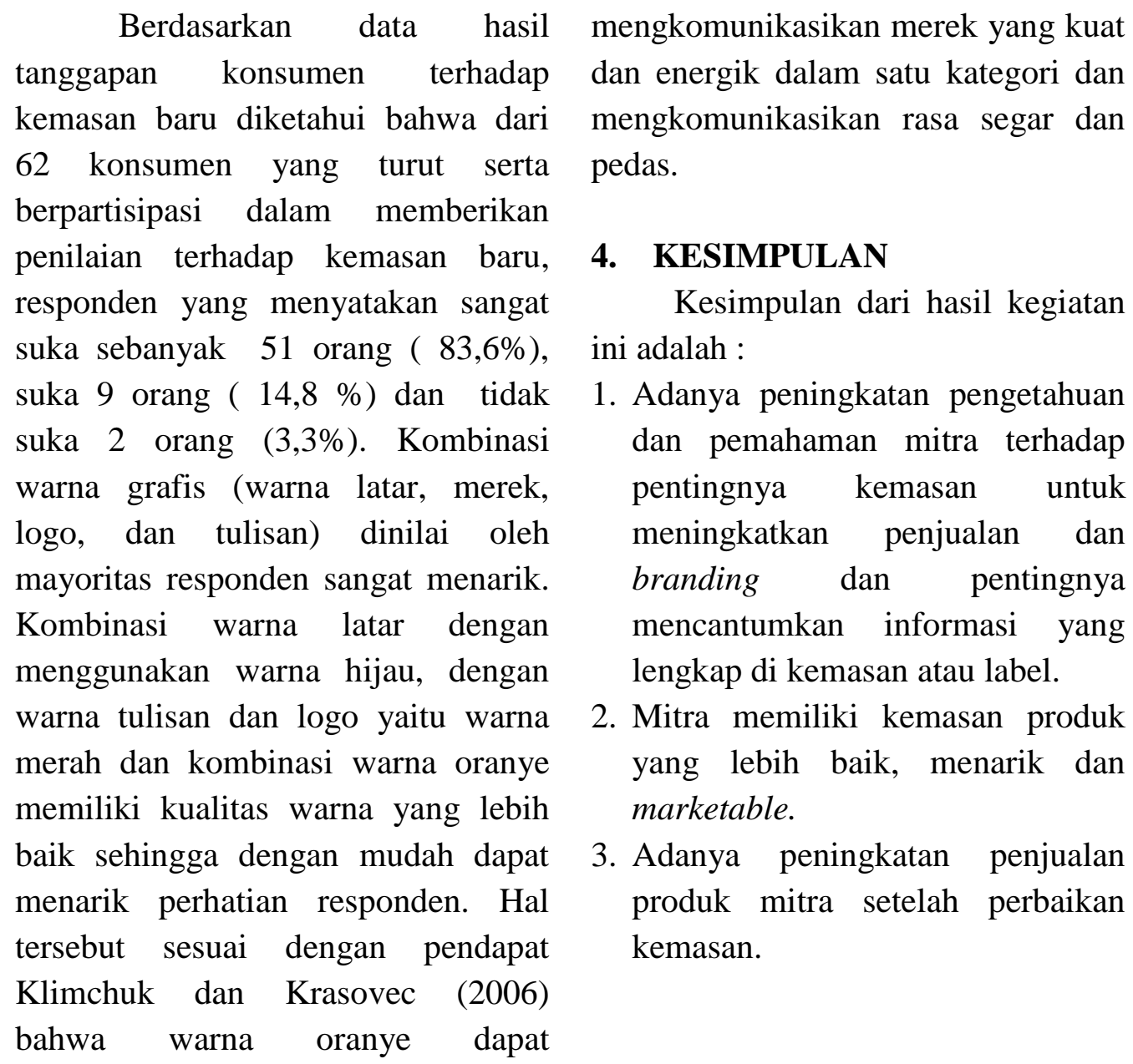




\section{UCAPAN TERIMAKASIH}

Terima kasih disampaikan kepada Kementerian Riset, Teknologi dan Pendidikan Tinggi atas hibah yang diberikan melalui program Kegiatan Iptek bagi Masyarakat tahun 2018, sehingga kegiatan ini dapat terlaksana dengan baik dan lancar. Ucapan serupa juga disampaikan kepada P3KM Politeknik Negeri Ketapang atas dukungannya dalam kegiatan ini.

\section{REFERENSI}

Adhy Putra. H, Kurniawati. E.P, 2012. Penyusunan Laporan Keuangan untuk Usaha Kecil Menengah (UKM) Berbasis Standar Akuntansi Keuangan Etentitas Tanpa Akuntabilitas Publik (SAK ETAP). Proceeding for Call Paper. Pekan Ilmiah Dosen FEB. UKSW. Salatiga.

Anggawirya, E., 2014. Akuntansi Berdasarkan Prinsip

Akuntansi Indonesia. PT Ercontara Rajawali. Jakarta

Cenadi,C.S., 2000. Peranan Desain

Kemasan dalam Dunia

Pemasaran. Jurnal Nirmana Volume [2] No. 1, Januari 2000: $92-103$.

Handayani, S. M. dan Sundari, M.T., 2016. Pemberdayaan Wanita Tani Melalui Pembuatan Keripik Belut Daun Singkong di Kecamatan Jumantono Kabupaten Karanganyar. Jurnal
Dianmas. Volume [5]. Nomor

2. Hal. 23 - 34.

Klimchuck MR, Krasovec SA., 2006. Desain Kemasan.(Alih Bahasa dari Bahasa Inggris Bob Sabran). Jakarta (ID): Erlangga. [Judul asli: Packaging Design]

LPPI, 2015. Profil Bisnis Usaha Mikro, Kecil dan Menengah (UMKM). Lembaga Pengembangan Perbankan Indonesia Bekerjasama dengan Bank Indonesia. Jakarta.

Mudra. I.W., 2010. Desain Kemasan Produk. Pusat Penelitian Seni Kreasi Baru. LP2M ISI Denpasar.

Nugrahani. R., 2015. Peran Desain Grafis Pada Label dan Kemasan Produk Makanan UMKM. Jurnal Imajinasi Volume 2, Tahun 2015. Unnesa. Semarang.

Parnanto, N.H., Qonita, R.R.A., dan Harisudin, M. 2016. Laporan Kemajuan IbM Peningkatan Usaha Wingko Babat. Lembaga Penelitian dan Pengabdian Kepada Masyarakat. Universitas Sebelas Maret. Surakarta.

Siregar, R.A.D, 2017. Desain Kemasan Produk UMKM Makanan Ringan dengan Pengaruhnya Terhadap Minat Beli Konsumen Di Bogor. Institut Pertanian Bogor. 
DIFUSI

Volume 1, No. 2, Juli 2018

Sudaryanto, Ragimun dan Rahma

Rina Wijayanti., 2014.

Strategi pemberdayaan

UMKM dalam menghadapi

pasar Bebas ASEAN. Jurnal.

ISSN NO : 1978-6522

Uchyani, R. dan Irianto. H., 2016.

Pengembangan Pasar Produk

Olahan Kacang Melalui

Perbaikan Kemasan. AJIE-

Asian Journal of Innovation

and Entrepreneurship.

Volume 01. No. 01. Januari

$2016: 62-67$. 